\title{
CRYOGENIC TANK TRADE STUDY FOR REUSABLE LAUNCH VEHICLES
}

H. KEVIN RIVERS

NASA LANGLEY RESEARCH CENTER HAMPTON, VA 23681-0001

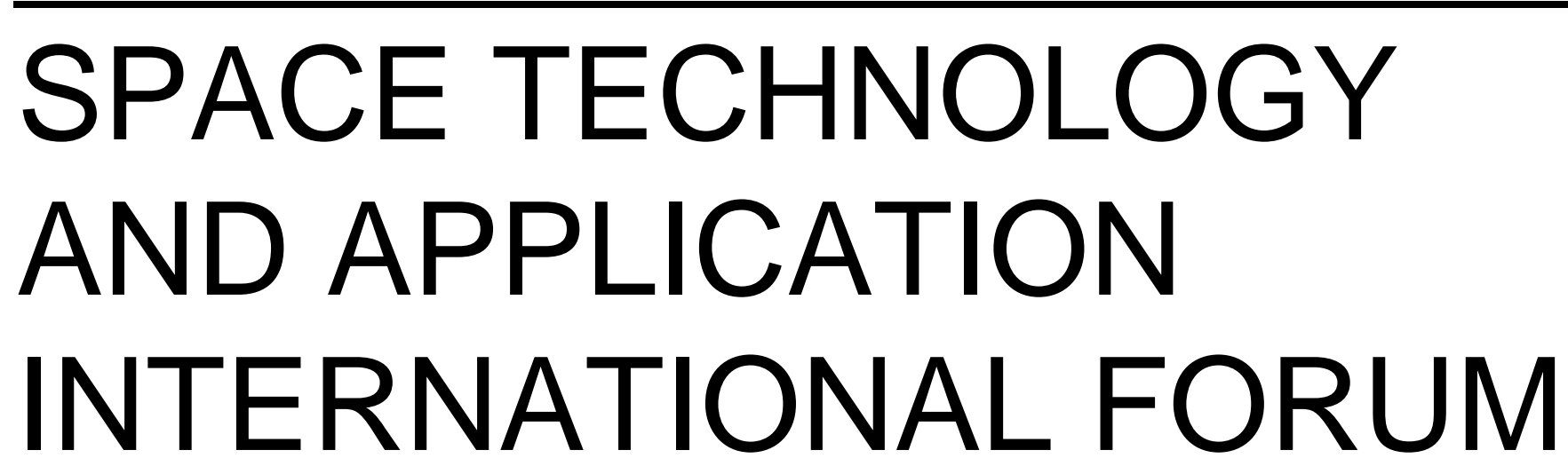

2nd Conference on Global Virtual Presence 2nd Conference on Orbital Transfer Vehicles

2nd Conference on Applications of Thermophysics in Micrc 4th Conference on Commercial Development of Space 4th Conference on Next Generation Launch Systems 16th Symposium on Nuclear Power and Propulsion 


\title{
Conformal Cryogenic Tank Trade Study for Reusable Launch Vehicles
}

\author{
H. Kevin Rivers ${ }^{1}$ \\ ${ }^{I}$ Thermal Structures Branch, Structures Division, MS-396, NASA Langley Research Center, Hampton, VA 23681. \\ (757)864-5428,h.k.rivers@larc.nasa.gov
}

\begin{abstract}
Future reusable launch vehicles may be lifting bodies with non-circular cross section like the proposed Lockheed-Martin VentureStar ${ }^{\mathrm{TM}}$. Current designs for the cryogenic tanks of these vehicles are dual-lobed and quad-lobed tanks which are packaged more efficiently than circular tanks, but still have low packaging efficiencies with large gaps existing between the vehicle outer mold line and the outer surfaces of the tanks. In this study, tanks that conform to the outer mold line of a non-circular vehicle were investigated. Four structural concepts for conformal cryogenic tanks and a quad-lobed tank concept were optimized for minimum weight designs. The conformal tank concepts included a sandwich tank stiffened with axial tension webs, a sandwich tank stiffened with transverse tension webs, a sandwich tank stiffened with rings and tension ties, and a sandwich tank stiffened with orthogrid stiffeners and tension ties. For each concept, geometric parameters (such as ring frame spacing, the number and spacing of tension ties or webs, and tank corner radius) and internal pressure loads were varied and the structure was optimized using a finite-element-based optimization procedure. Theoretical volumetric weights were calculated by dividing the weight of the barrel section of the tank concept and its associated frames, webs and tension ties by the volume it circumscribes. This paper describes the four conformal tank concepts and the design assumptions utilized in their optimization. The conformal tank optimization results included theoretical weights, trends and comparisons between the concepts, are also presented, along with results from the optimization of a quad-lobed tank. Also, the effects of minimum gauge values and non-optimum weights on the weight of the optimized structure are described in this paper.
\end{abstract}

\section{INTRODUCTION}

Future launch vehicles must be lightweight, fully reusable and easily maintained if low-cost access to space is to be achieved. The Reusable Launch Vehicle Program (RLV/X33) is a joint venture between the National Aeronautics and Space Administration (NASA) and Lockheed-Martin to develop such a vehicle. The proposed Lockheed-Martin VentureStar ${ }^{\mathrm{TM}}$ has a goal of reducing the cost of placing payloads into orbit by an order of magnitude (Cook, 1996). Lockheed-Martin is constructing the X33 vehicle, shown in Figure 1, a half-scale version of the VentureStar ${ }^{\mathrm{TM}}$ reusable launch vehicle (RLV), to test new reusable launch vehicle technologies.



FIGURE 1. Artist rendering of the RLV/X33 vehicle. 


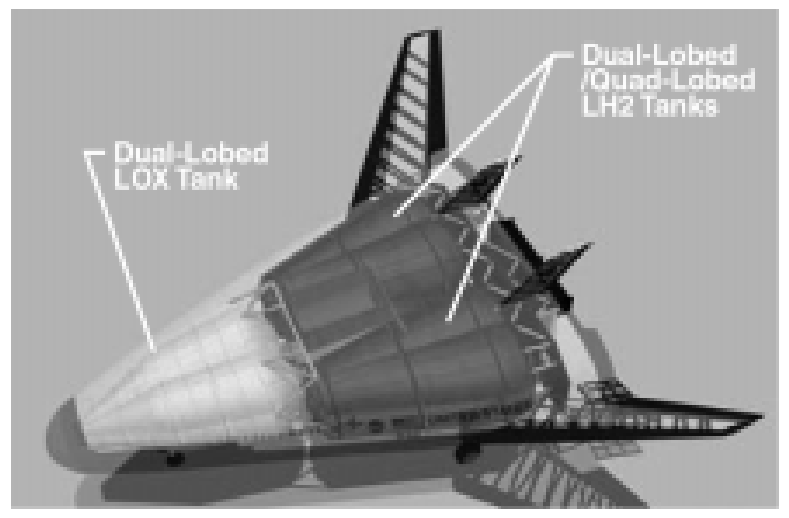

FIGURE 2. Structural arrangement of the RLV/X33 vehicle.

The Lockheed-Martin Reusable Launch Vehicle (RLV) concept is a lifting body with a non-circular cross-section, consequently, cylindrical cryogenic tanks can not be packaged efficiently inside the vehicle body. The cryogenic tanks proposed by Lockheed-Martin are dual-lobed liquid oxygen (LOX) tanks and dual-lobed/quad-lobed liquid hydrogen $\left(\mathrm{LH}_{2}\right)$ tanks. These tanks are shown in a schematic of the RLV/X33 structural arrangement in Figure 2. Although multi-lobed tanks are more efficiently packaged in this vehicle than cylindrical tanks, they do not conform to the outer surface of the vehicle leaving large gaps between the tank surfaces and the outer surface, or outer mold line (OML), of the vehicle where the lobes are joined and at the corners of the vehicle body. Figure 3 contains cross-sectional views of an RLV/X33 vehicle at locations with LOX tanks and $\mathrm{LH}_{2}$ Tanks, in these cross-sectional views, the gaps between the tanks and the vehicle body are shown for both multi-lobed tanks and conformal tanks (differentiated by shading). Extra structure is required to bridge these gaps for multi-lobed tanks and attach thermal protection systems (TPS) to the tanks. The weight of this extra structure is significant.

If conformal tanks, see Figure 3, are employed, the volumetric efficiency of the vehicle's tanks can be increased, and the extra TPS support structure required for multi-lobed tanks can be eliminated, perhaps significantly reducing the weight of the vehicle. Conformal tanks have not been considered in the past because these structures react the pressure loads through bending as well as membrane loading while cylindrical tanks react the pressure loads through membrane loading only. When compared directly with membrane-loaded tank structures, conformal tanks do not appear to be weight competitive. However, the conformal tank concepts evaluated in this study show potentially significant increases in volumetric and packaging efficiencies and would reduce the TPS support structure required on multi-lobed tank structures.

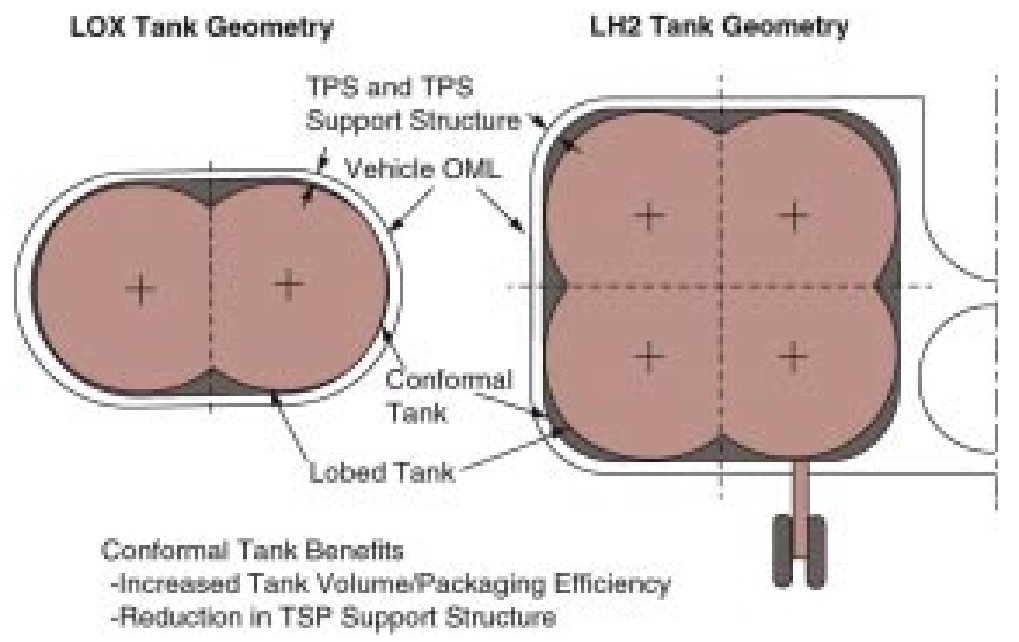

FIGURE 3. Cross section of the RLV/X33 vehicle showing both conformal and multi-lobed tank profiles. 


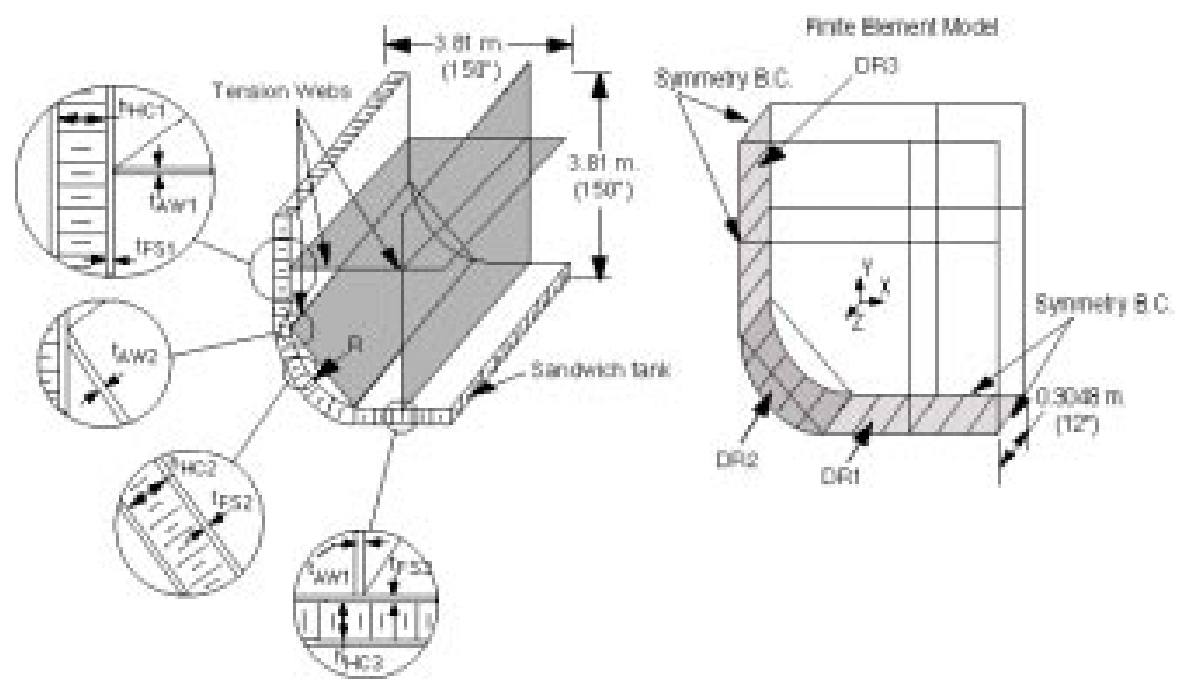

FIGURE 4. Concept 1, a honeycomb-sandwich tank structure stiffened with axial tension webs.

The proposed propulsion system for the RLV/X33 is a linear aero-spike engine. The Since the thrust loads produced by this engine are along a straight line, integration of this engine with conformal tanks is more efficient than with multi-lobed tanks. The load paths for distributing the thrust laods into the tank structure are improved with conformal tanks. When consideration is given to improved thrust load paths, as well as to the elimination of extra TPS support structure, conformal tanks may become weight competitive with multi-lobed tank structures. These improvements have a scaled effect on reducing the total weight of the vehicle, in that small reductions in structural weight result in large reductions in gross lift-off weight (GLOW) for a vehicle sized to deliver a fixed payload to orbit (Wu, 1999).

Four concepts for conformal cryogenic tanks and an axial-tension-web-stiffened quad-lobed tank concept were studied. The conformal tank concepts included a sandwich tank stiffened with axial tension webs, a sandwich tank stiffened with transverse tension webs, a sandwich tank stiffened with rings and tension ties, and a sandwich tank stiffened with orthogrid stiffeners and tension ties. For each concept, geometric parameters (such as ring frame spacing, the number and spacing of tension ties or webs, and tank corner radius) and internal pressure loads were varied and the structure was optimized using a finite-element-based optimization procedure.

\section{TANK CONCEPTS}

In this trade study four conformal tank concepts and a quad-lobed tank concept were studied. Each concept was a honeycomb sandwich structure with a minimum core height of $1 \mathrm{in}$. for cryogenic insulation. Each concept was stiffened as follows: concept 1 with axial tension webs; concept 2 with transverse tension webs; concept 3 with ring frames and tension ties; and concept 4 with orthogrid stiffeners and tension ties. The quad-lobed tank concept did not include any ring frames or longitudinal stiffeners.

TABLE 1. Material Properties

\begin{tabular}{|c|c|c|c|c|c|c|c|c|c|c|c|}
\hline Material & $\begin{array}{c}\mathbf{E}_{11} \\
\text { (MPa) }\end{array}$ & $\begin{array}{c}\mathbf{E}_{22} \\
\text { (MPa) }\end{array}$ & $\begin{array}{c}\mathrm{G}_{12} \\
(\mathrm{MPa})\end{array}$ & $v_{12}$ & $v_{21}$ & $\begin{array}{c}\text { Max } \\
\text { Tension } \\
\text { (MPa) }\end{array}$ & $\begin{array}{c}\text { Max } \\
\text { Tension } \\
\text { (MPa) }\end{array}$ & $\begin{array}{l}\text { Max. } \\
\text { Shear } \\
\text { (MPa) }\end{array}$ & $\begin{array}{c}\alpha_{11} \\
(\mu \mathrm{m} / \mathbf{m})\end{array}$ & $\begin{array}{c}\alpha_{22}, \\
(\mu \mathrm{m} / \mathbf{m})\end{array}$ & $\begin{array}{r}\text { Density } \\
\left(\mathrm{kg} / \mathrm{m}^{3}\right)\end{array}$ \\
\hline $\begin{array}{l}\text { Graphite } \\
\text { Composite }\end{array}$ & 68,966 & 68,966 & 265,241 & 0.31 & 0.30 & 413.8 & 413.8 & 544.8 & 4.8 & 4.8 & $1,577.5$ \\
\hline $\begin{array}{l}\text { Honeycomb } \\
\text { Core }\end{array}$ & N/A & N/A & N/A & N/A & N/A & N/A & N/A & N/A & N/A & N/A & 80.1 \\
\hline
\end{tabular}



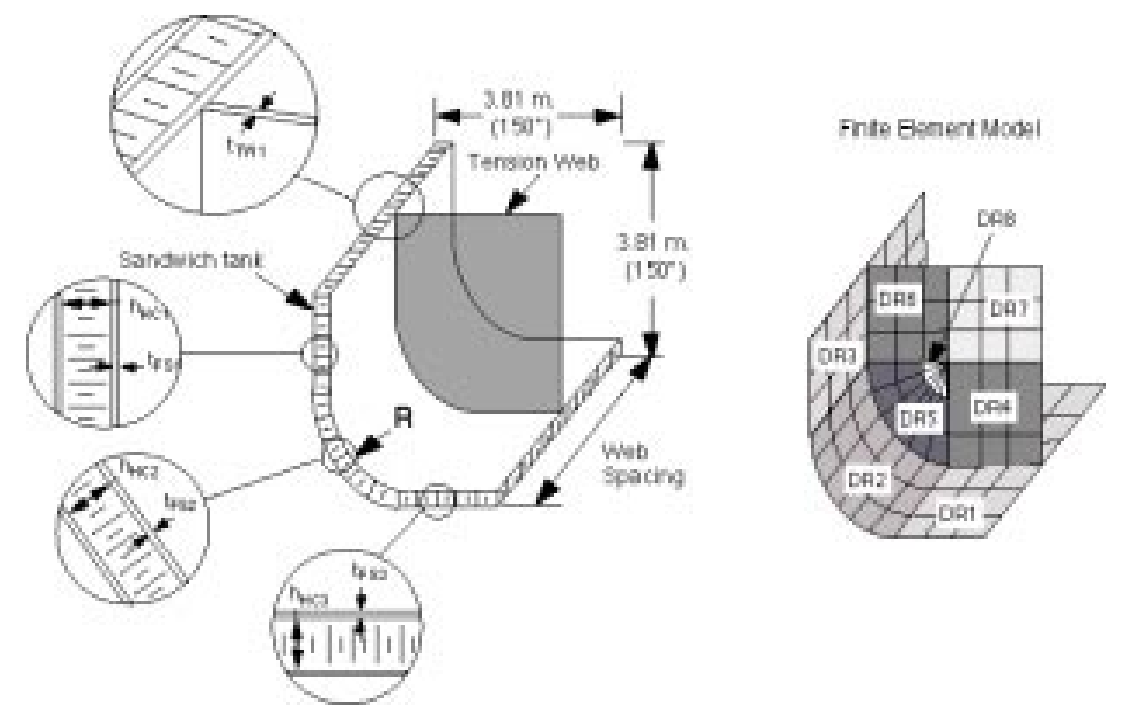

FIGURE 5. Concept 2, a honeycomb-sandwich tank structure stiffened with transverse tension webs.

In each concept, the honeycomb sandwich tank wall consisted of quasi-isotropic graphite composite face sheets, with material properties as shown in Table 1 , and a $80.1 \mathrm{~kg} / \mathrm{m}^{3}\left(5 \mathrm{lb} / \mathrm{ft}^{3}\right)$ honeycomb core material. The frames, stiffeners, tension ties and tension webs of each concept were also quasi-isotropic composite material with properties identical to those of the honeycomb sandwich face sheets. A finite element model of a quarter section $3.81-\mathrm{m}$ by $3.81-\mathrm{m}$ (150-in. by 150 -in.) of a symmetric cryogenic tank was developed for each concept. Symmetry boundary conditions were imposed along the edges of the model and an internal pressure load was applied to the tank wall. Other loads, such as thrust loads, inertial loads and aerodynamic loads were not included in this analysis.

Concept 1 was a honeycomb sandwich tank stiffened with axial tension webs. Sketches of Concept 1 and the finite element model used to model Concept 1 are shown in Figure 4. In the sketch, areas of the concept have been enlarged to show the section properties that were sized in different regions of the tank to achieve a minimum weight design. Concept 1 was modeled as using a finite element model. For Concept 1, the tank wall was modeled with
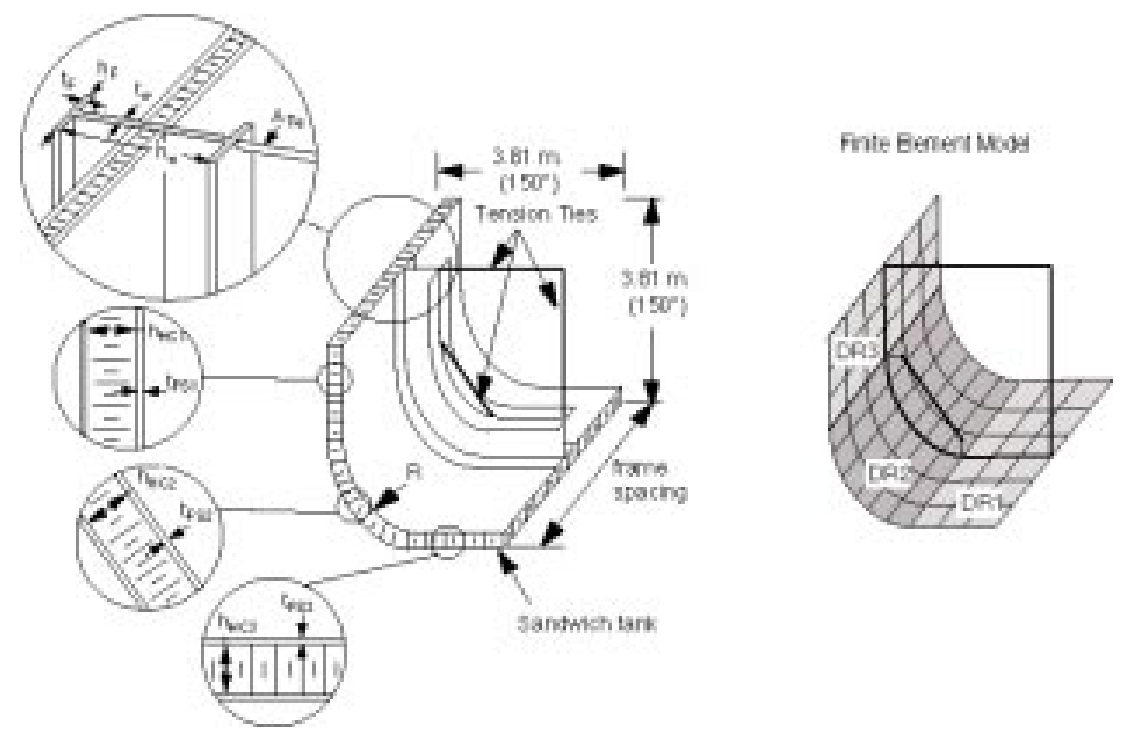

FIGURE 6. Concept 3, a honeycomb-sandwich tank structure stiffened with a ring frame and tension ties. 


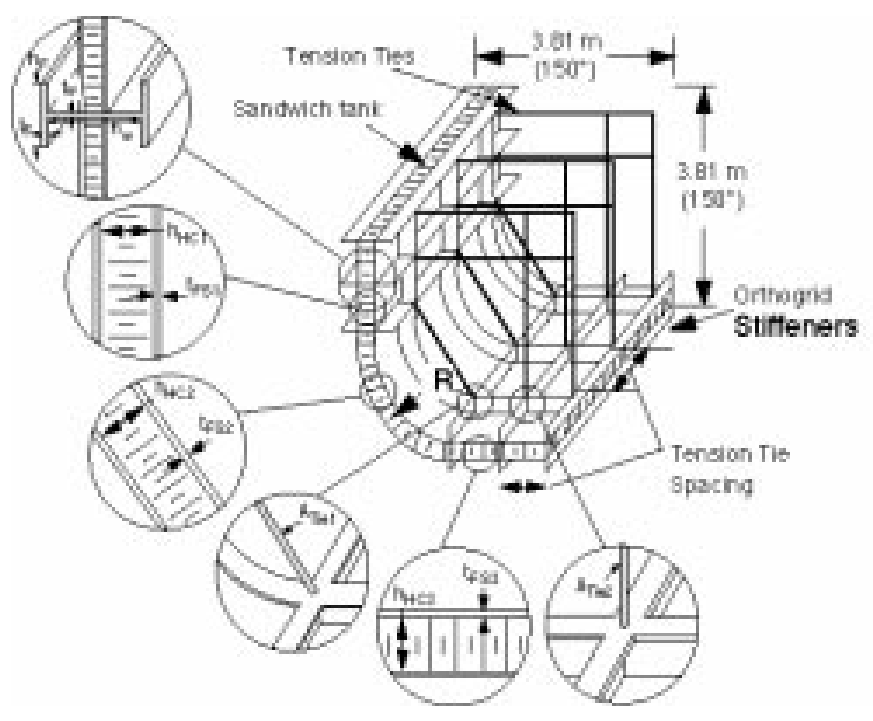

Fnte Bemert Mosel

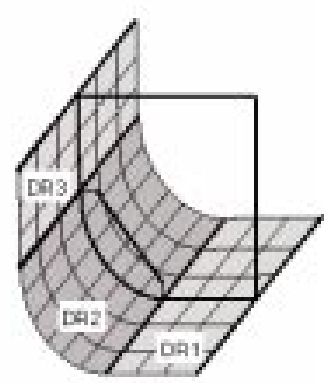

FIGURE 7. Concept 4, a honeycomb-sandwich tank stiffened with orthogrid stiffeners and tension ties.

4-node generalized plate elements, which have both membrane and bending capability. These elements were isotropic honeycomb sandwich elements. The honeycomb core in these elements acted as a spacer between the face sheets, and its stiffness was ignored. The tension webs were modeled as 2-node rod elements with axial load carrying capability only. A tension web was placed across the curved section of the tank to react the bending moment at the intersections of the flat and curved sections of the tank and to reduce bending in the curved section of the tank. Horizontal and vertical tension webs were spaced $0.635 \mathrm{~m}$ (25 in.) apart on the flat sections of the tank. The tank wall was divided into three design regions, indicated as DR1, DR2 and DR3 in Figure 4. Both the face sheet thickness, $\mathrm{t}_{\mathrm{FS} i}$, and honeycomb core height, $\mathrm{h}_{\mathrm{HC} i}$, in each design region were sized (where $I$ corresponds to the design region number). The vertical and horizontal tension ties were grouped together and their thickness, $t_{\mathrm{AW} 1}$, was sized. The corner tension web thickness, $\mathrm{t}_{\mathrm{AW} 2}$, was independently sized. Cases with a corner radius of $0.635 \mathrm{~m}(25$ in.), $1.904 \mathrm{~m}$ (75 in.), and $10.635 \mathrm{~m}$ (125 in.) were optimized for internal pressure loads of $137.9 \mathrm{KPa}$ (20 psi) and 275.9 KPa (40 psi).

Concept 2 was a honeycomb sandwich tank stiffened with transverse tension webs. Sketches of Concept 2 and its finite element model are shown in Figure 5. The tank wall and tension webs were modeled with isotropichoneycomb-sandwich generalized plate elements. Again, the tank wall was divided into three design regions, and the face sheet thickness, $\mathrm{t}_{\mathrm{FSi}}$, and honeycomb core height, $\mathrm{h}_{\mathrm{HCi}}$, of each design region, DR1 through DR3, were sized to meet strength requirements. The tension web was divided into five design regions, indicated as DR4 through DR8 in Figure 5. The web thickness, $t_{\mathrm{TW}}$, in each design region was sized to meet the strength requirements for that region and the core height was set to zero. The corner radius was either $0.635 \mathrm{~m}$ ( $25 \mathrm{in}$.) or $2.538 \mathrm{~m}$ (100 in.), the web spacing was varied between $0.457 \mathrm{~m}$ (18 in.), $0.914 \mathrm{~m}$ (36 in.), and $1.371 \mathrm{~m}$ (54 in.), and each case was sized for pressures of $137.9 \mathrm{KPa}(20 \mathrm{psi})$ and $275.9 \mathrm{KPa}(40 \mathrm{psi})$.

Concept 3 was a honeycomb sandwich tank stiffened with a ring frame with an "I" cross section and tension ties. Sketches of Concept 3 and its finite element model are shown in Figure 6. Again the tank wall is modeled with isotropic-honeycomb-sandwich generalized plate elements. The ring frames were modeled as 2-node wide-flange beam elements with an "I" shaped cross section. Tension ties were connected to the ring frame. A corner tension tie was placed across the curved section of the tank to reduce bending in that region of the tank wall, while vertical and horizontal tension ties were spaced $0.635 \mathrm{~m}$ (25 in.) apart. The tank wall was divided into three design regions with face sheet thickness, $\mathrm{t}_{\mathrm{FSi}}$, and core height, $\mathrm{h}_{\mathrm{HCi}}$, sized in each design region, DR1 through DR3. The flange length, $\mathrm{h}_{\mathrm{F}}$, flange thickness, $\mathrm{t}_{\mathrm{F}}$, web height, $\mathrm{h}_{\mathrm{W}}$, and web thickness, $\mathrm{t}_{\mathrm{W}}$, of the ring frame were also design variables. The vertical and horizontal tension ties used the same design variable, their area, $A_{\text {tie }}$, in the sizing. The area of the corner tension tie, $\mathrm{A}_{\text {ctie, }}$, was sized independently. The corner radius was set at either $0.635 \mathrm{~m}(25 \mathrm{in}$.) or $2.538 \mathrm{~m}$ (100 in.), and the ring spacing was varied between $0.457 \mathrm{~m}$ (18 in.), $0.914 \mathrm{~m}$ (36 in.), and $1.371 \mathrm{~m} \mathrm{(54} \mathrm{in.).} \mathrm{Each}$ case was sized for internal pressure loads of $137.9 \mathrm{KPa}(20 \mathrm{psi})$ and $275.9 \mathrm{KPa}$ (40 psi). 


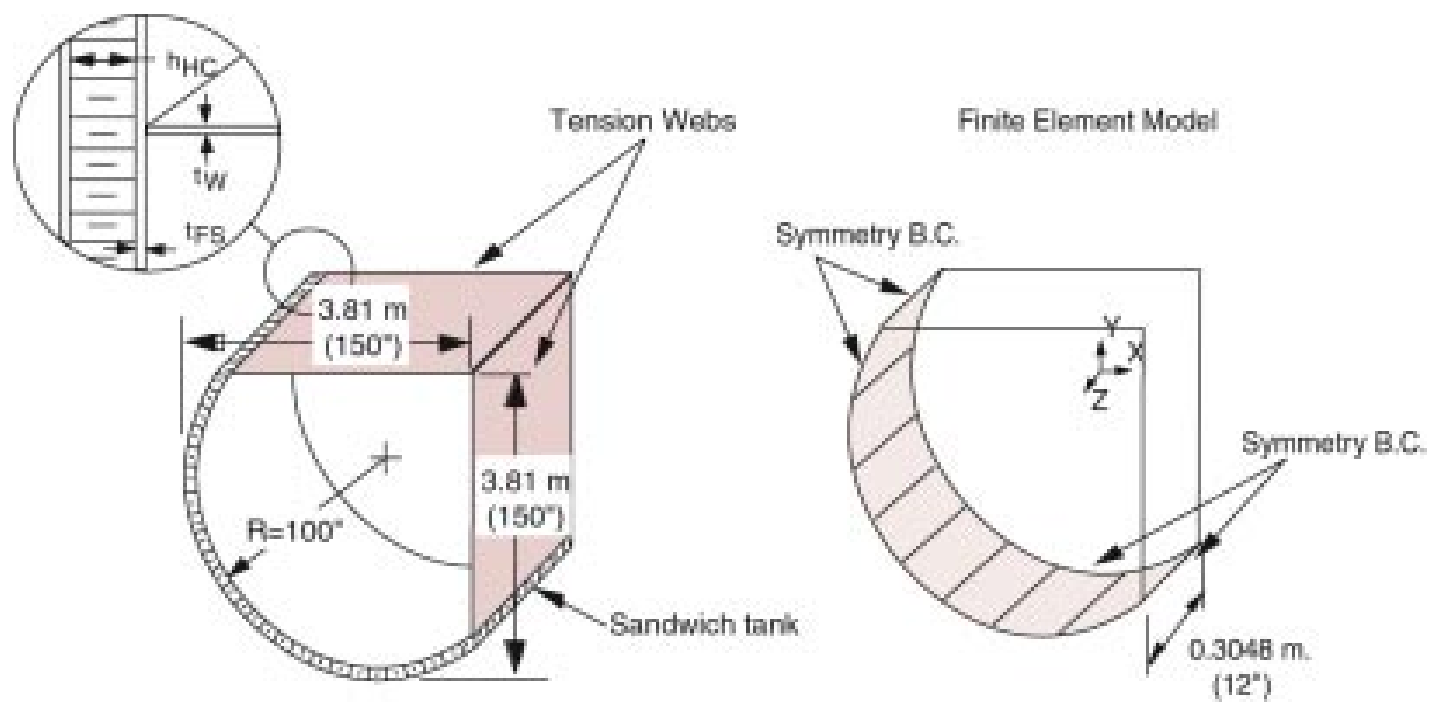

FIGURE 8. A honeycomb sandwich quad-lobed tank structure stiffened with tension webs.

Concept 4 was a honeycomb sandwich tank wall stiffened with orthogrid stiffeners and tension ties. Sketches of Concept 4 and its finite element model are shown in Figure 7. The tank wall was modeled with isotropichoneycomb-sandwich generalized plate elements. The orthogrid stiffeners were placed at either $0.304 \mathrm{~m}$ (12 in.), $0.457 \mathrm{~m}$ (18 in.) or $0.609 \mathrm{~m}$ (24 in.) spacing along the flat sections of the tank wall and were modeled as 2-node wide-flange beam elements with an "I" shaped cross section. The tension ties were placed at the intersections of the orthogrid stiffeners as well as across the curved section of the tank wall and were modeled as 2-node rod elements. The tank wall was divided into three design regions, DR1 through DR3, as indicated in Figure 7, with face sheet thickness, $\mathrm{t}_{\mathrm{FSi}}$, and core height, $\mathrm{h}_{\mathrm{HCi}}$, values sized for each design region. The design variables for all the axial stiffeners were linked. The design variables for the transverse stiffeners were independently linked. The stiffener design variables were the flange length, $h_{F}$, flange thickness, $t_{F}$, web height, $h_{W}$, and web thickness, $t_{W}$, of the stiffeners. All of the vertical and horizontal tension ties were linked to use the same design variable, and the corner tension ties were independently sized. The corner radius was set at $0.635 \mathrm{~m}(25 \mathrm{in}$.) and each case was sized for internal pressure loads of $137.9 \mathrm{KPa}(20 \mathrm{psi})$ and $275.9 \mathrm{KPa}(40 \mathrm{psi})$.

A quad-lobed tank structure was also studied, and sketches of the quad-lobed structure and its finite element model are shown in Figure 8 . The tank lobe radii were $2.538-\mathrm{m}(100$-in.). This geometry was chosen because its volume was very close to the maximum volume achievable within a $3.81-\mathrm{m}$ by $3.81-\mathrm{m}$ (150-in. by 150 -in.) cross-sectional area with a quad-lobed tank. The quad-lobed tank was modeled with a one-element-deep finite element model using isotropic-honeycomb-sandwich generalized plate elements to model the tank wall and rod elements to model the tension webs. The sandwich face sheet thickness, the core height, and the tension web area were the design variables sized in the analysis. The tank was sized for a 137.9-KPa (20 psi) internal pressure load.

\section{STRUCTURAL OPTIMIZATION PROCEDURE}

Each concept was optimized with fixed geometric parameters, such as ring frame spacing, the number and spacing of tension ties or webs, tank corner radius and flat lengths, and for fixed internal pressure loads using a finiteelement-based optimization procedure (Martin, 1996) in the Engineering Analysis Language (EAL) finite element analysis system (Whetstone, 1983). A number of optimized designs were also generated for parametric variations of the geometric parameters and internal pressure loads. The optimization procedure was written primarily in the EAL command language. Three external processors, which were written in FORTRAN generate equivalent stiffnesses and evaluate stress and local buckling constraints for various structural cross sections. Several built-up cross sections common in aircraft design are available for use, and for this study, the isotropic-sandwich-plate, the isotropic-plate, the wide-flange-beam, and the rod structural cross sections were used. Design variables are assumed 


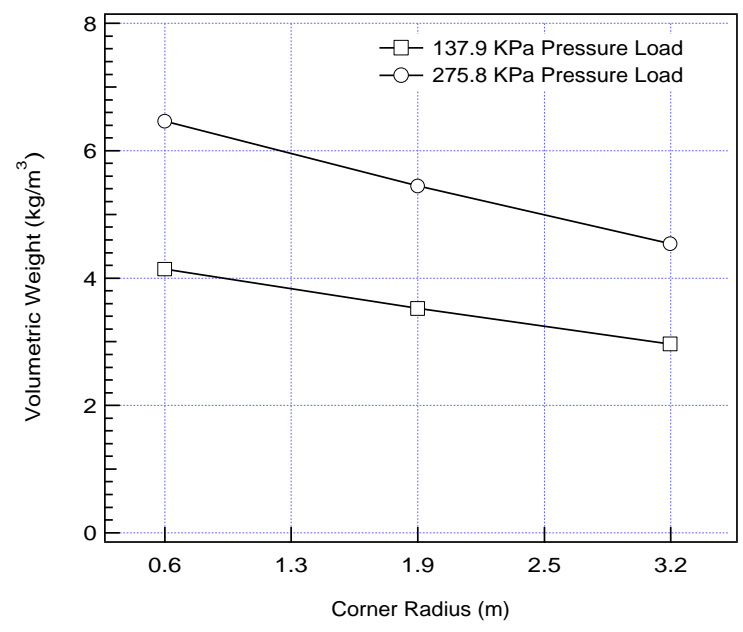

FIGURE 9. Volumetric weights for Concept 1, the axial-tension-web-stiffened sandwich tank.

to be continuous in this procedure, and can vary between user specified bounds. Sensitivity calculations use the semi-analytic method (Martin, 1996), and an extensive effort has been made to increase the execution speed and reduce storage requirements. The optimization is performed by implementation of the MINOS V5.4 linear programming routine (Murtagh, 1993) in a sequential linear programming procedure.

\section{STRUCTURAL OPTIMIZATION RESULTS}

Concept 1 , the axial tension web stiffened tank, was optimized for cases with the corner radius equal to $0.635 \mathrm{~m}$ (25 in.), $1.904 \mathrm{~m}$ (75 in.), and $3.173 \mathrm{~m}$ (125 in.). For each case, the conformal tank was optimized for internal pressure loads of $137.9 \mathrm{KPa}(20 \mathrm{psi})$ and $275.9 \mathrm{KPa}(40 \mathrm{psi})$. For each individual case, theoretical volumetric weights were calculated by dividing the tank weight (including stiffeners) by the volume the tank circumscribes. These theoretical volumetric weights, plotted as functions of corner radius, are given in Figure 9.

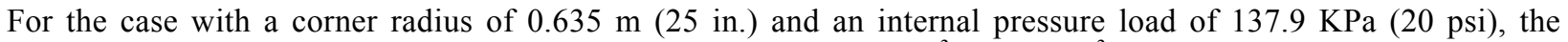
theoretical volumetric weight of the optimized structure is $4.15 \mathrm{~kg} / \mathrm{m}^{3}\left(0.26 \mathrm{lb} / \mathrm{ft}^{3}\right)$ of tank volume. The optimized design variables (and their bounds) for this case are given in Table 2. For this case, the core height in the curved section is sized to its lower bound $25.38 \mathrm{~mm}$ (1-in.) which is the minimum core height required for cryogenic insulation. As a comparison, the theoretical volumetric weight of a 3.808-m (150-in.) radius cylindrical membrane tank with cryogenic insulation $\left(25.38-\mathrm{mm}\right.$ thick and $80.1-\mathrm{kg} / \mathrm{m}^{3}\left(5-\mathrm{lb} / \mathrm{ft}^{3}{ }^{3}\right)$ density) and without ring frames would be $2.18 \mathrm{~kg} / \mathrm{m}^{3}\left(0.14 \mathrm{lb} / \mathrm{ft}^{3}{ }^{3}\right)$. Although this weight is theoretical and does not include structural stiffeners, Concept 1 is nearly twice as heavy as a membrane loaded cylindrical tank

TABLE 2. Design Variables for Concept 1 with a $0.635-\mathrm{m}$ Corner Radius, a $0.635 \mathrm{~m}$ tension web spacing, and a $137.9-\mathrm{KPa}$ Internal Pressure Load

\begin{tabular}{|c|c|c|c|}
\hline Design Variables & Optimum Value & Lower Bound & Upper Bound \\
\hline Top flat face sheet thickness, $\mathrm{t}_{\mathrm{FS} 1}(\mathrm{~mm})$ & 1.19 & 0.254 & 25.4 \\
\hline Top flat honeycomb core height, $\mathrm{h}_{\mathrm{HC} 1}(\mathrm{~mm})$ & 40.98 & 25.4 & 101.5 \\
\hline Curved section Face sheet thickness, $\mathrm{t}_{\mathrm{FS} 2}(\mathrm{~mm})$ & 0.584 & 0.254 & 25.4 \\
\hline Curved Section honeycomb core height, $\mathrm{h}_{\mathrm{HC} 2}(\mathrm{~mm})$ & 25.40 & 25.4 & 101.5 \\
\hline Side flat face sheet thickness, $\mathrm{t}_{\mathrm{FS} 3}(\mathrm{~mm})$ & 1.19 & 0.254 & 25.4 \\
\hline Side flat honeycomb core height, $\mathrm{h}_{\mathrm{HC} 3}(\mathrm{~mm})$ & 40.98 & 25.4 & 101.5 \\
\hline Vertical and horizontal web thickness, $\mathrm{t}_{\mathrm{AW} 1}(\mathrm{~mm})$ & 0.457 & 0.254 & 50.76 \\
\hline Corner web thickness, $\mathrm{t}_{\mathrm{AW} 2}(\mathrm{~mm})$ & 0.406 & 0.254 & \\
\hline
\end{tabular}




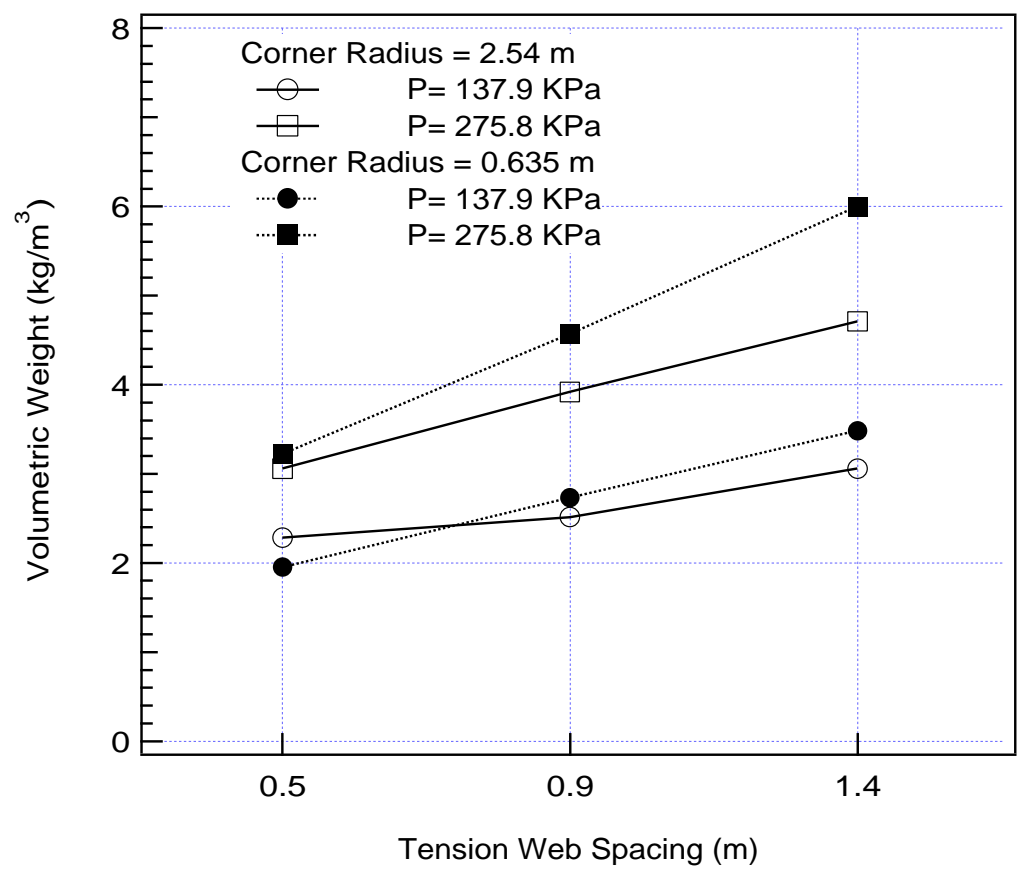

FIGURE 10. Volumetric weights for Concept 2, the transverse-tension-web-stiffened sandwich tank.

Concept 2, the honeycomb-sandwich tank stiffened with transverse tension webs, was optimized for cases with a corner radius of $0.635 \mathrm{~m}$ ( $25 \mathrm{in}$.), and $2.54 \mathrm{~m}$ (100 in.), and for cases with transverse tension web spacing of $0.457 \mathrm{~m}$ (18 in.), $0.914 \mathrm{~m}$ (36 in.), and $1.371 \mathrm{~m}$ (54 in.). Each case was optimized for an internal pressure load of $137.9 \mathrm{KPa}$ (20 psi) and $275.9 \mathrm{KPa}(40 \mathrm{psi})$. Theoretical volumetric weights were calculated for each case and are shown graphically in Figure 10.

For the case with a corner radius of $0.635 \mathrm{~m}$ ( $25 \mathrm{in}$.) and a transverse tension web spacing of $0.457 \mathrm{~m}$ (18 in.), with the internal pressure load of $137.9 \mathrm{KPa}(20 \mathrm{psi})$, the theoretical volumetric weight of the optimized structure is $2.24 \mathrm{~kg} / \mathrm{m}^{3}\left(0.14 \mathrm{lb} / \mathrm{ft}^{3}\right)$ of tank volume. The optimized design variables (and their variable bounds) are given in Table 3. For the transverse tension web, the thicknesses in each design region (DR4-DR8) are given. Each design variable was sized to its lower bound for this case.

TABLE 3. Design Variables for Concept 2 with a 0.635-m Corner Radius, 0.457-m Tension Web Spacing, and a 137.9-KPa Internal Pressure Load

\begin{tabular}{lrrr}
\hline Design Variables & Optimum Value & Lower Bounds & Upper Bounds \\
\hline Top flat face sheet thickness, $\mathrm{t}_{\mathrm{FS} 1}(\mathrm{~mm})$ & 0.254 & 0.254 & 25.4 \\
Top flat honeycomb core height, $\mathrm{h}_{\mathrm{HC} 1}(\mathrm{~mm})$ & 25.4 & 25.4 & 101.5 \\
Curved section Face sheet thickness, $\mathrm{t}_{\mathrm{FS} 2}(\mathrm{~mm})$ & 0.254 & 0.254 & 25.4 \\
Curved Section honeycomb core height, $\mathrm{h}_{\mathrm{HC} 2}(\mathrm{~mm})$ & 25.4 & 25.4 & 101.5 \\
Side flat face sheet thickness, $\mathrm{t}_{\mathrm{FS} 3}(\mathrm{~mm})$ & 0.254 & 0.254 & 25.4 \\
Side flat honeycomb core height, $\mathrm{h}_{\mathrm{HC} 3}(\mathrm{~mm})$ & 0.254 & 0.254 & 101.5 \\
DR4 Transverse tension web thickness, $\mathrm{t}_{\mathrm{TW} 1}(\mathrm{~mm})$ & 0.254 & 0.254 & 50.76 \\
DR5 Transverse tension web thickness, $\mathrm{t}_{\mathrm{TW} 2}(\mathrm{~mm})$ & 0.254 & 0.254 & 50.76 \\
DR6 Transverse tension web thickness, $\mathrm{t}_{\mathrm{TW} 3}(\mathrm{~mm})$ & 0.254 & 0.254 & 50.76 \\
DR7 Transverse tension web thickness, $\mathrm{t}_{\mathrm{TW} 4}(\mathrm{~mm})$ & 0.254 & 0.254 & 50.76 \\
DR8 Transverse tension web thickness, $\mathrm{t}_{\mathrm{TW} 5}(\mathrm{~mm})$ & & 50.76 \\
\hline
\end{tabular}




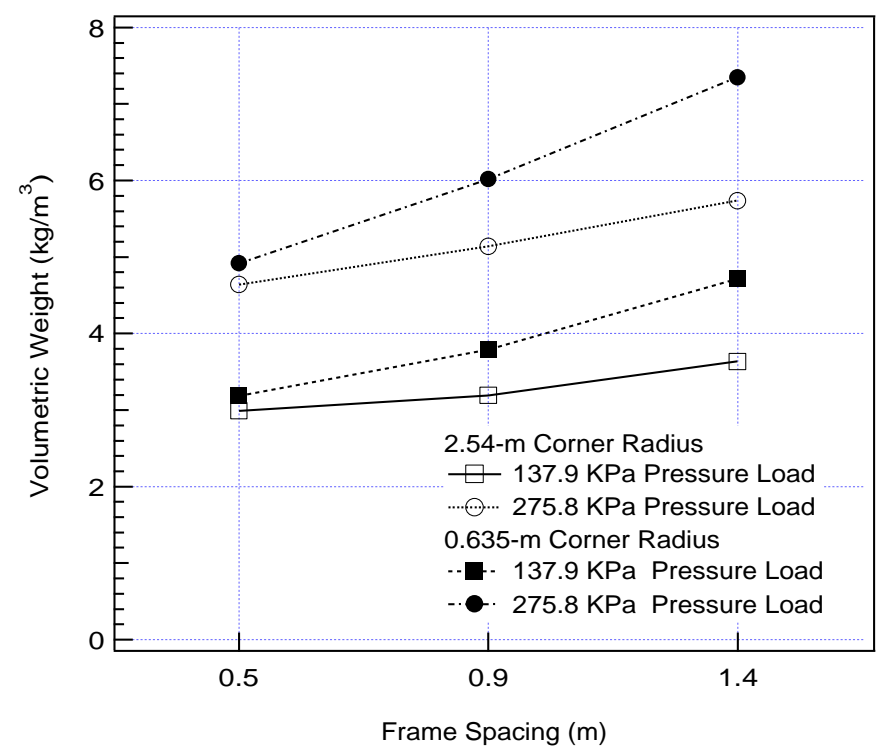

FIGURE 11. Volumetric weights for Concept 3, the ring-frame-and-tension-tie-stiffened sandwich tank.

Concept 3 was a sandwich tank stiffened with ring frames and tension ties. Cases with a corner radius of $0.635 \mathrm{~m}$ (25 in.) and $2.538 \mathrm{~m}$ (100 in.) and with ring frame spacing of either $0.457 \mathrm{~m}$ (18 in.), $0.914 \mathrm{~m}$ (36 in.) or $1.371 \mathrm{~m}$ (54 in.) were optimized for internal pressure loads of $137.9 \mathrm{KPa}(20 \mathrm{psi})$ and $275.9 \mathrm{KPa}$ (40 psi). Theoretical volumetric weights were calculated for each case and are reported in Figure 11.

For the case with a corner radius of $0.635 \mathrm{~m}$ (25 in.), a ring frame spacing of $0.457 \mathrm{~m}$ (18 in.), and an internal pressure load of $137.9 \mathrm{KPa}(20 \mathrm{psi})$, the theoretical volumetric weight of the optimized structure was $3.19 \mathrm{~kg} / \mathrm{m}^{3}$ $\left.\left(0.20 \mathrm{lb} / \mathrm{ft}^{3}\right)^{3}\right)$ of tank volume. The optimized design variables (and their minimum and maximum variable bounds) for this case are given in Table 4. In all three design regions of the tank wall (top flat, curved section, side flat), both the face sheet thickness and honeycomb core height were sized to their minimum variable bounds, $0.254 \mathrm{~mm}(0.01$ in.) and $25.4 \mathrm{~mm}$ (1 in.), respectively.

TABLE 4. Design Parameters for Concept 3 with a 0.635-m Corner Radius, 0.457-m Ring Frame Spacing, and a 137.9 KPa Internal Pressure Load.

\begin{tabular}{|c|c|c|c|}
\hline Design Variables & Optimum Value & Lower Bounds & Upper Bounds \\
\hline Top flat face sheet thickness, $\mathrm{t}_{\mathrm{FS} 1}(\mathrm{~mm})$ & 0.254 & 0.254 & 25.4 \\
\hline Top flat honeycomb core height, $\mathrm{h}_{\mathrm{HC} 1}(\mathrm{~mm})$ & 25.4 & 25.4 & 101.5 \\
\hline Curved section Face sheet thickness, $\mathrm{t}_{\mathrm{FS} 2}(\mathrm{~mm})$ & 0.254 & 0.254 & 25.4 \\
\hline Curved Section honeycomb core height, $\mathrm{h}_{\mathrm{HC} 2}(\mathrm{~mm})$ & 25.4 & 25.4 & 101.5 \\
\hline Side flat face sheet thickness, $\mathrm{t}_{\mathrm{FS} 3}(\mathrm{~mm})$ & 0.254 & 0.254 & 25.4 \\
\hline Side flat honeycomb core height, $\mathrm{h}_{\mathrm{HC} 3}(\mathrm{~mm})$ & 25.4 & 25.4 & 101.5 \\
\hline Ring Frame flange length, $\mathrm{h}_{\mathrm{f}}(\mathrm{mm})$ & 55.8 & 50.76 & 253.81 \\
\hline Ring Frame flange thickness, $\mathrm{t}_{\mathrm{f}}(\mathrm{mm})$ & 1.614 & 1.269 & 253.81 \\
\hline Ring Frame web height, $h_{w}(\mathrm{~mm})$ & 170.1 & 50.76 & 304.57 \\
\hline Ring frame web thickness, $\mathrm{t}_{\mathrm{W}}(\mathrm{mm})$ & 2.23 & 1.269 & 253.81 \\
\hline Vertical and horizontal tension tie area, $\mathrm{A}_{\text {tiel }}\left(\mathrm{mm}^{2}\right)$ & 201.8 & 32.21 & 6441.8 \\
\hline Corner tension tie area, $\mathrm{A}_{\text {tie } 2}\left(\mathrm{~mm}^{2}\right)$ & 117.8 & 32.21 & 6441.8 \\
\hline
\end{tabular}




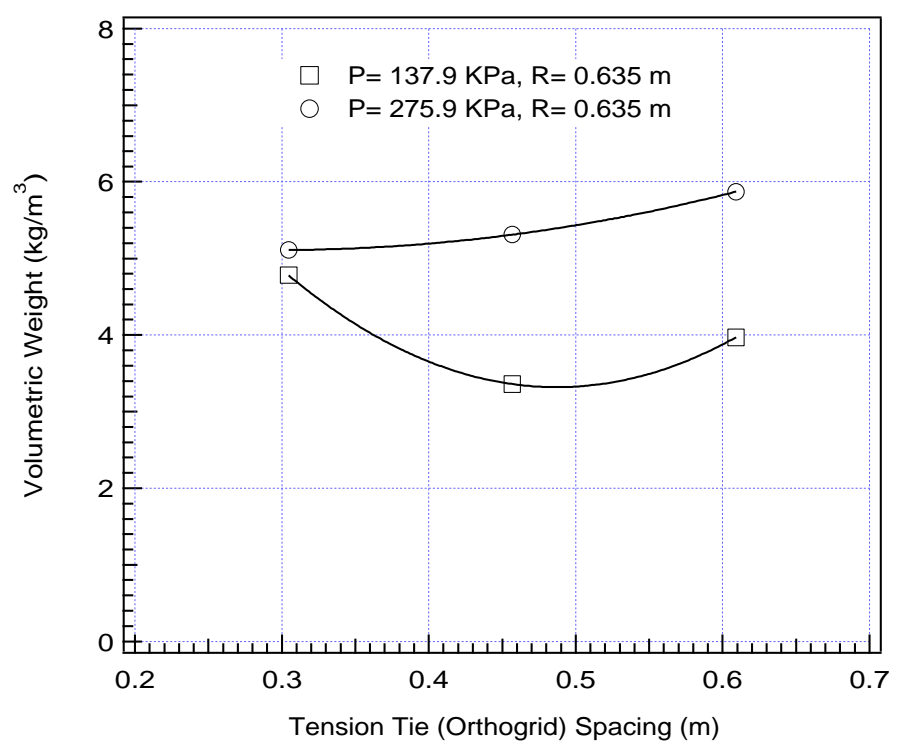

FIGURE 12. Volumetric weights for Concept 4, the orthogrid-and-tension-tie-stiffened sandwich tank.

Concept 4 was a honeycomb sandwich tank stiffened with orthogrid stiffeners and tension ties. Cases with a corner radius of $0.635 \mathrm{~m}$ (25 in.), and with a tension tie (orthogrid) spacing of $0.304 \mathrm{~m} \mathrm{(12} \mathrm{in.),} 0.457 \mathrm{~m} \mathrm{(18} \mathrm{in.)} \mathrm{and} 0.609$ m (24 in.) were optimized for internal pressure loads of $137.9 \mathrm{KPa}(20 \mathrm{psi})$ and $275.9 \mathrm{KPa}(40 \mathrm{psi})$. Theoretical volumetric weights were calculated for each case and are reported in Figure 12.

For the case with a corner radius equal to $0.635 \mathrm{~m}$ ( $25 \mathrm{in}$.), a tension tie spacing equal to $0.457 \mathrm{~m}$ (18 in.), and an internal pressure load of $137.9 \mathrm{KPa}(20 \mathrm{psi})$, the theoretical volumetric weight of the optimized structure was $3.19 \mathrm{~kg} / \mathrm{m}^{3}\left(0.21 \mathrm{lbm} / \mathrm{ft}^{3}{ }^{3}\right)$ of tank volume. The optimized design variables, as well as their respective minimum and maximum variable bounds, are shown in Table 5. It is interesting to note that the sandwich core height in the curved section of the tank was taller than in the flat sections of the tank, $20.3 \mathrm{~mm}(0.8 \mathrm{in}$.) in the flat section versus $12.7 \mathrm{~mm}$ ( 0.5 in.) in the curved section. This is believed due to the absence of any axial stiffeners in the curved section of the tank wall.

TABLE 5. Design Variables for Concept 4 with a $0.635-\mathrm{m}$ Corner Radius, $0.457-\mathrm{m}$ Tension Tie (Orthogrid) Spacing, and a 137.9 KPa Internal Pressure Load

\section{Design Variables}

Top flat face sheet thickness, $\mathrm{t}_{\mathrm{FS} 1}(\mathrm{~mm})$

Top flat honeycomb core height, $\mathrm{h}_{\mathrm{HC} 1}(\mathrm{~mm})$

Curved section Face sheet thickness, $\mathrm{t}_{\mathrm{FS} 2}(\mathrm{~mm})$

Curved Section honeycomb core height, $\mathrm{h}_{\mathrm{HC} 2}(\mathrm{~mm})$

Side flat face sheet thickness, $\mathrm{t}_{\mathrm{FS} 3}(\mathrm{~mm})$

Side flat honeycomb core height, $\mathrm{h}_{\mathrm{HC} 3}(\mathrm{~mm})$

Axial Orthogrid Stiffener flange length, $\mathrm{h}_{\mathrm{f} 1}(\mathrm{~mm})$

Axial Orthogrid Stiffener flange thickness, $t_{\mathrm{fl}}(\mathrm{mm})$

Axial Orthogrid Stiffener web height, $\mathrm{h}_{\mathrm{w} 1}(\mathrm{~mm})$

Axial Orthogrid Stiffener web thickness, $t_{\mathrm{w} 1}(\mathrm{~mm})$

Transverse Orthogrid Stiffener flange length, $\mathrm{h}_{\mathrm{f} 2}(\mathrm{~mm})$

Transverse Orthogrid Stiffener flange thickness, $\mathrm{t}_{\mathrm{f} 2}(\mathrm{~mm})$

Transverse Orthogrid Stiffener web height, $h_{w 2}(\mathrm{~mm})$

Transverse Orthogrid Stiffener web thickness, $t_{\mathrm{w} 2}(\mathrm{~mm})$

Vertical and horizontal tension tie area, $\mathrm{A}_{\text {tiel }}\left(\mathrm{mm}^{2}\right)$

Corner tension tie area, $\mathrm{A}_{\text {tie } 2}\left(\mathrm{~mm}^{2}\right)$

$\begin{array}{rrr}\text { Optimum Value } & \text { Lower Bounds } & \text { Upper Bounds } \\ 0.305 & & \\ 12.92 & 0.254 & 101.5 \\ 0.533 & 25.4 & 101.5 \\ 0.769 & 0.254 & 101.5 \\ 0.305 & 25.4 & 101.5 \\ 12.92 & 0.254 & 101.5 \\ 19.87 & 25.4 & 101.5 \\ 1.27 & 0.254 & 203.0 \\ 121.22 & 1.27 & 38.1 \\ 2.31 & 50.76 & 304.6 \\ 10.25 & 1.27 & 38.1 \\ 1.40 & 0.254 & 203.0 \\ 58.5 & 1.27 & 38.1 \\ 1.62 & 50.76 & 203.0 \\ 97.92 & 1.27 & 38.1 \\ 63.13 & 6.45 & 12884.0 \\ & 6.45 & 12884.0\end{array}$




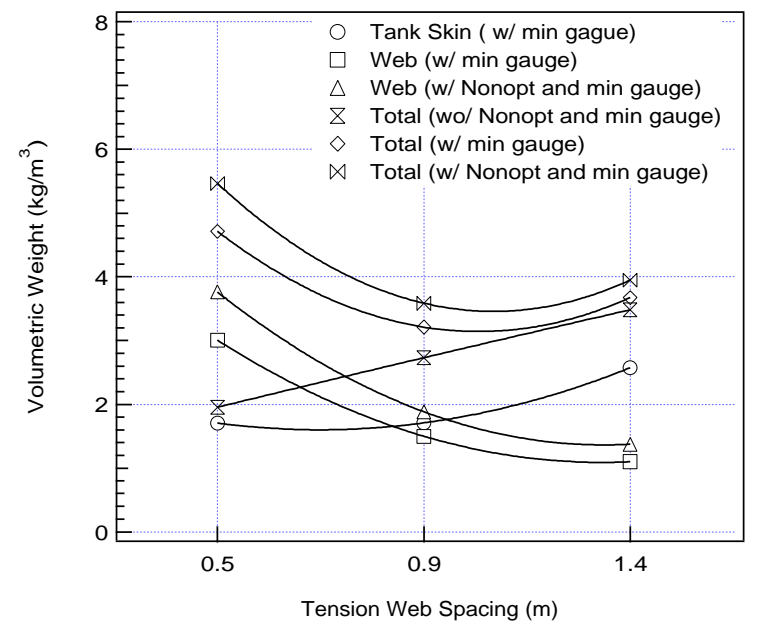

FIGURE 13. Volumetric weights for concept 2 with the addition of non-optimum weights and minimum gauge constraints.

A 2.54-m (100-in.) radius quad-lobed tank, stiffened with axial tension webs was optimized for an internal pressure of $137.9 \mathrm{KPa}$. The design variables were sized as follows: face sheet thickness was $0.457 \mathrm{~mm}$; sandwich core height was $25.4 \mathrm{~mm}$; and tension web thickness was $0.457 \mathrm{~mm}$. The volumetric weight for this case was $2.18 \mathrm{~kg} / \mathrm{m}^{3}(0.14$ $\mathrm{lb} / \mathrm{ft}^{3}$ ) of tank volume.

\section{MINIMUM GAUGE AND NON-OPTIMUM WEIGHT EFFECTS}

From the previous results, concept 2, a sandwich tank stiffened with transverse tension webs, was the lightest conformal tank concept and the optimum tension web spacing for Concept 2 appears to be $0.457 \mathrm{~m}$ (18 in.). However, these results are theoretical and do not include the effects of minimum gauge constraints on variables such as face sheet thickness and tension web thickness, or the addition of non-optimum weights (like those associated with joints). In order to quantify these effects, Concept 2 and the quad-lobed tank concept were studied more closely by applying minimum gauge constraints believed realistic for manufacturability and by adding non-optimum weights as a percentage of the tension web weight. The laminate thicknesses were also adjusted in increments of $0.14 \mathrm{~mm}$ (the thickness of a typical ply) to obtain a buildable structure.

Concept 2 was again optimized for cases with a corner radius of $0.635 \mathrm{~m}$ (25 in.), $1.904 \mathrm{~m}$ (75 in.) and $10.635 \mathrm{~m}$ (125 in.), and with a tension web spacing of $0.457 \mathrm{~m}$ (18 in.), $0.914 \mathrm{~m} \mathrm{(36} \mathrm{in.)} \mathrm{and} 1.371 \mathrm{~m} \mathrm{(54} \mathrm{in.),} \mathrm{with} \mathrm{internal}$

TABLE 6. Design variables for Concept 2 with a $0.635 \mathrm{~m}$ corner radius, $0.457 \mathrm{~m}$ tension web spacing, and a $137.9 \mathrm{KPa}$ internal pressure load with non-optimum weights and minimum gauge variable bounds applied

\begin{tabular}{|c|c|c|c|}
\hline Design Variables & Optimum Value & Lower Bounds & Upper Bounds \\
\hline Top flat face sheet thickness, $t_{\mathrm{FS} 1}(\mathrm{~mm})$ & 0.834 & 0.834 & 6.35 \\
\hline Top flat honeycomb core height, $\mathrm{h}_{\mathrm{HCl}}(\mathrm{mm})$ & 25.4 & 25.4 & 76.14 \\
\hline Curved section Face sheet thickness, $\mathrm{t}_{\mathrm{FS} 2}(\mathrm{~mm})$ & 0.834 & 0.834 & 6.35 \\
\hline Curved Section honeycomb core height, $\mathrm{h}_{\mathrm{HC} 2}(\mathrm{~mm})$ & 25.4 & 25.4 & 76.14 \\
\hline Side flat face sheet thickness, $\mathrm{t}_{\mathrm{FS} 3}(\mathrm{~mm})$ & 0.834 & 0.834 & 6.35 \\
\hline Side flat honeycomb core height, $\mathrm{h}_{\mathrm{HC} 3}(\mathrm{~mm})$ & 25.4 & 25.4 & 76.14 \\
\hline DR4 Transverse tension web thickness, $\mathrm{t}_{\mathrm{TW} 1}(\mathrm{~mm})$ & 0.558 & 0.558 & 6.35 \\
\hline DR5 Transverse tension web thickness, $\mathrm{t}_{\mathrm{TW} 2}(\mathrm{~mm})$ & 0.558 & 0.558 & 6.35 \\
\hline DR6 Transverse tension web thickness, $\mathrm{t}_{\mathrm{TW} 3}(\mathrm{~mm})$ & 0.558 & 0.558 & 6.35 \\
\hline DR7 Transverse tension web thickness, $\mathrm{t}_{\mathrm{TW} 4}(\mathrm{~mm})$ & 0.558 & 0.558 & 6.35 \\
\hline DR8 Transverse tension web thickness, $\mathrm{t}_{\mathrm{TW} 5}(\mathrm{~mm})$ & 0.558 & 0.558 & 6.35 \\
\hline
\end{tabular}


pressure loads of $137.9 \mathrm{KPa}(20 \mathrm{psi})$. For the case with a $0.635-\mathrm{m}(25 \mathrm{in}$.) corner radius, a $0.457-\mathrm{m}$ (18 in.) tension web spacing, and a 137.9-KPa (20 psi) pressure load, the design variables and their bounds, including minimum gauges are given in Table 6 . With realistic minimum gauge constraints, the structure is sized to minimum gauge for this case as well as for the case with a tension web spacing of 0.914-m (36 in.). Theoretical volumetric weight (structural weight per unit of tank volume) for each case, with and without non-optimum weights and minimum gauge constraints, are shown as functions of tension web spacing in Figure 13. Volumetric weights for the tank skin and tension membrane (with and without a $25 \%$ non-optimum weight) are also shown. When non-optimum weights and minimum gauge constraints are applied, the optimum tension web spacing is approximately $0.914 \mathrm{~m}(36 \mathrm{in}$.) and the volumetric weight for that concept was $3.59 \mathrm{~kg} / \mathrm{m}^{3}\left(0.22 \mathrm{lb} / \mathrm{ft}^{3}\right)$ of tank volume.

The quad-lobed tank structure was optimized for an internal pressure load of $137.9 \mathrm{KPa}$ and a new volumetric weight was calculated. When minimum gauge constraints (identical to those for Concept 2) were applied and a nonoptimum weight $\left(25 \%\right.$ of the tension web weight) was added, the volumetric weight increased to $3.03 \mathrm{~kg} / \mathrm{m}^{3}(0.19$ $\left.\mathrm{lb} / \mathrm{ft}^{3}\right)$.

\section{CONCLUDING REMARKS}

Of the concepts studied, Concept 2 (the transverse tension web stiffened sandwich tank) appears to be the lightest structural concept for conformal tanks with a theoretical volumetric weight of $2.24 \mathrm{~kg} / \mathrm{m}^{3}\left(0.14 \mathrm{lb} / \mathrm{ft}^{3}\right)$. For the case with a $0.635-\mathrm{m}$ corner radius, loaded with a $137.9 \mathrm{KPa}$ internal pressure, and without consideration of minimum gauge constraints and non-optimum weights, the optimum solution for this concept appears to be at $0.457-\mathrm{m}$ tension web spacing. However, when non-optimum weights are added and minimum gauge constraints are applied, the optimum solution (lightest weight structure) is closer to $0.914-\mathrm{m}$ tension web spacing with a weight of $3.59 \mathrm{~kg} / \mathrm{m}^{3}$ $\left(0.22 \mathrm{lb} / \mathrm{ft}^{3}\right)^{3}$.

To understand the other concepts more completely, similar studies, which include realistic non-optimum weights and minimum gauge constraints, should be performed. Also, weight reductions possible with structural tailoring of composites should be investigated as well as the impact of additional load cases on optimized designs. Since the conformal tank would have a higher volume/packaging efficiency than multi-lobed tanks, would have a more direct load path for thrust loads, and would require less TPS support structure, a study of the impact of conformal tanks on total vehicle weight should be performed. When consideration is given to the entire vehicle system, the conformal tank may be viable for future reusable launch vehicles with non-circular cross sections.

\section{ACKNOWLEDGMENTS}

The author would like to thank the following: Carl Martin, Univ. of Wisconsin, for his assistance with the finite element models and structural optimization procedure used in this study; Chauncey Wu, Thermal Structures Branch, NASA Langley Research Center, for his assistance with the structural optimization and concept definition for this study; John Dorsey, Thermal Structures Branch, NASA Langley Research Center, for his guidance in defining the concepts and geometric variables studied; and Steve Scotti, Head, Thermal Structures Branch, for his guidance in preparing and executing this study.

\section{REFERENCES}

Cook, S. A., "The X-33 Advanced Technology Demonstrator,” AIAA-96-1195, April 1996.

Martin, C. J., Jr., "Documentation for a Structural Optimization Procedure Developed Using the Engineering Analysis Language (EAL)," NASA Contractor Report 201632, October 1996.

Mortagh, B. A. and Saunders, M. A., "MINOS 5.4 User's Guide (preliminary)," Technical Report SOL 83-20R, Systems Optimization Laboratory, Stanford University. Stanford, CA, 1983 (revised 1993).

Whetstone, W. D., "EISI-EAL Engineering Analysis Reference Manual,” Engineering Information Systems, Inc., July 1983.

Wu, K. C. and Lepsch, R. A., "Nontangent, Developed Contour Bulkheads for a Wing-Body Single Stage Launch Vehicle," Thirty-seventh AIAA Aerospace Sciences Meeting and Exhibit, Reno, NV, January 11-14, 1999. 